\title{
A Two-Phase Longitudinal Study on Nutrition and School Performance among Grades 1- 3 Children in Kwazulu-Natal, South Africa
}

\author{
Oluwakemi Rachel Ajayi* \\ School of Mathematics, University of Kwazulu-Natal, South Africa
}

Submission: March 16, 2017; Published: May 08, 2017

*Corresponding author: Oluwakemi Rachel Ajayi, School of Mathematics, Statistics and Computer Science, University of Kwazulu-Natal, South Africa, Tel: +27744228818; Email: 214582629@stu.ukzn.ac.za

\section{Introduction}

Factors thought to be relevant to a child's cognitive development in this environment were measured at baseline when the children were 4-6 years pf age, and several were found to be associated with scores in at least one of the three cognitive tests administered to the children: the area where the children lived (site), gender, whether children received pre -school education, their HIV status, the level of parental education, height-for-age, and hemoglobin. The evidence showed a significant association between site, poor nutrition as measured by height-for-age z-scores on the one hand, and cognitive outcomes as measured by the Grover Counter Test and subtests of the KABC-11.on the other [1,2].

The mini review investigates whether the association between these factors and cognitive outcomes persisted when the children were assessed two years later, and which other variables measured at time two in this two-phase study have an effect on cognitive outcomes in these children, now 6-8 years old. These questions are important in identifying priority nutrition and education needs in this location in order to direct public policies and practice in government nutrition, health and education sectors when tackling child poverty here and in similar disadvantaged areas both in South Africa and further afield.

Approximately two years after the baseline study, the Phase 1 instruments to measure cognition were repeated, Grover counter test and Kaufman's KABC-11 subtests. In addition several other factors were measured: demographic factors, geographic location of the homestead, pre-school education, parental level of education, socioeconomic status, child's health and nutritional status. Ethical approval was obtained for all study procedures and interview material from the University of KwaZuluNatal Biomedical Research Ethics (BF036/07) Committee and the Columbia University Institutional Review Board. We hypothesized that the children's cognitive development would be influenced by their baseline scores, current nutritional, socioeconomic status, their exposure to formal schooling, and their parents' educational level.

The analysis examined the long-term association and the differences in demographic variables which included the site (geographic area), child variables: gender, pre-school education, child's HIV status and socio-economic status (SES), maternal and paternal level of education, child's hemoglobin level, and anthropometric measure (height-for-age z-scores) on children's cognitive performance. These were measured by the Grover Counter Test and subtests from Kauffman's KABC11. Linear regression analysis of the test scores was performed to examine the associated factors and the differences in the means of cognitive test scores from both phases of the study were calculated. Following this, actual differences between the cognitive scores were computed (i.e. test score at phase 2- test score at phase 1) and a linear regression model was used to determine the association of the variables of interest with the differences in children's cognitive scores.

The study was conducted in an area which ranged from periurban to deep rural terrain in the Kwazulu-Natal province of South Africa [3]. The province is the most populous of the nine provinces in South Africa and has the highest number of children living in households with per capital income below the poverty line [3]. Although adjacent, the five local authority areas which make up the total study site have different characteristics: They are, governed by different local authorities and have extreme differences in terrain and proximity to urban areas.

Of the 1581 children included in phase 1, 1383 also participated in phase $2(87.5 \%)$ in the cognitive and anthropometric testing. The children who were now between the ages of 6-8 years were then followed up within the five adjacent geographical areas, extending from peri-urban to deep rural area. The association between poor nutrition and cognitive 
outcomes among 4-6 year old children was well-established at the baseline and the follow-up study provides evidence of persistence over a two year period of the link between poor nutrition and cognitive outcomes among 6-8 year old children in KwaZulu-Natal, South Africa.

This study found that significant effects of variables relating to the child's sex, HIV status and hemoglobin level on their cognitive outcomes when the children were between four and six years of age were no longer apparent two years later. On the other hand whether or not children had attended pre-school, their area of residence, and height-for-age which had significant effects on cognitive outcomes at four to six years of age persisted as statistically significant factors affecting cognitive test scores when the children were between six and eight years of age. Further, at this age, the effect of paternal level of education was also significantly associated with the cognitive test scores of the children. The findings from this study may assist policy makers and implementing authorities in selecting key areas for intervention in order to promote the cognitive development of the children living in these and the many other similarly disadvantaged communities in Africa. As economists have pointed out, investment in the development of children is not only ethically important, but also lays a firm foundation for the country's economic development [4].

\section{References}

1. Grover VM, Sebate KM (2000) Revised manual for the Grover-Counter Scale of Cognitive development. Pretoria: Human Sciences Research Council.

2. Lichtenberger EO, Volker MA, Kaufman AS, Kaufman NL (2006) Assessing Gifted Children with the Kaufman Assessment Battery for Children-Second Edition (KABC-II). Gifted Education International 21(2-3): 99-126.

3. Kvalsvig JD, Taylor M, Kauchali S, Chhagan M (2013) Acknowledging Methodological Complexity in Assessing Children in HIVAffected Communities in KwaZulu-Natal Province, South Africa. Neuropsychology of Children in Africa pp. 37-68.

4. Repositioning nutrition as central to development: a strategy for largescale action (2006) Washington DC, USA.

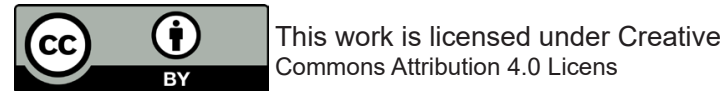

Your next submission with Juniper Publishers will reach you the below assets

- Quality Editorial service

- Swift Peer Review

- Reprints availability

- E-prints Service

- Manuscript Podcast for convenient understanding

- Global attainment for your research

- Manuscript accessibility in different formats (Pdf, E-pub, Full Text, Audio)

- Unceasing customer service

Track the below URL for one-step submission https://juniperpublishers.com/online-submission.php 